\title{
DEVELOPMENT AND VALIDATION OF THE METHOD FOR DETERMINATION OF RELATED IMPURITIES IN RIBOXIN TABLETS
}

\author{
M.V.Rosada, N.Yu.Bevz, V.A.Georgiyants \\ National University of Pharmacy \\ 53, Pushkinska Str., 61002, Kharkiv. E-mail: rosada@list.ru
}

Key words: standardization; Riboxin; tablets; related impurities; HPLC

Riboxin (inosine) is used in medicine for treating cardiovascular diseases, so the number of dosage forms containing this substance as an active ingredient is constantly increasing at the Ukrainian pharmaceutical market. When developing quality control methods for a dosage form containing one active substance it is advisable to carry out tests on the presence of related impurities besides identification and assay tests. The article presents the data concerning development of the method for determination of related impurities (hypoxanthine, guanosine) in riboxine tablets using HPLC. The analysis was carried out using a HPLC column (125×4 mm i.d., $5 \mu \mathrm{m}$ particles) filled with "Lichrospher $60 \mathrm{RP}$ select B"sorbent. The mobile phase adjusted with the phosphate buffer to $\mathrm{pH} 3.5$ was used. The UV detection was performed at $250 \mathrm{~nm}$. The validation characteristics have been studied using the acceptance criteria for the tolerances of the content not more than $0.5 \%$ for each impurity, and they confirm specificity (the absence of the effect of excipients), linearity, precision (convergence), accuracy $\left(\Delta_{z}=0.79 \leq \max \right.$ $\Delta_{z}=5.0, \delta=0.21 \leq \max \delta=0.26, a=0.48, r=0.99997>0.9976$ for hypoxanthine, and $\Delta_{z}=0.83 \leq \max \Delta_{z}=5.0$, $\delta=0.17 \leq \max \delta=0.28, a=0.21, r=0.99997>0.9976$ for guanosine), and the application range for the method proposed.

РОЗРОБКА ТА ВАЛІДАЦІЯ МЕТОДИКИ ВИЗНАЧЕННЯ СУПРОВІДНИХ ДОМІШОК У ТАБЛЕТКАХ РИБОКСИН М.В.Росада, Н.Ю.Бевз, В.А.Георгіяни

Ключові слова: стандартизація; рибоксин; таблетки; супровідні домішки; метод ВЕРХ

Рибоксин (інозин) застосовують у медичній практиці для лікування серцево-судинних захворювань, тому кількість готових лікарських форм, що містять як активний фрармацевтичний інгредієнт саме цю речовину, на фрармацевтичному ринку України постійно зростає. При розробці методик контролю якості на готову лікарську форму, що містить одну діючу речовину, доцільно окрім випробувань на ідентифрікацію та кількісне визначення також проводити випробування на вміст супутніх домішок. У запропонованій роботі наводяться дані по розробці методики визначення супровідних домішок (діпоксантин, гуанозин) рибоксину в таблетках з використанням методу високоефективної рідинної хроматографрії. Визначення проводили на колониі розміром 125×4 мм, заповненій сорбентом «Lichrospher 60 RP select В» з розміром часток 5 мкм, використовували рухому фразу на основі фоосфатного буфрерного розчину з рН 3,5 та УФ-детектування за довжини хвилі 250 нм. Вивчені валідаційні характеристики з використанням критеріїв прийнятності для допусків вмісту не більше 0,5\% для кожної з домішок підтверджують специфічність (відсутність впливу допоміжних речовин), лінійність, прецизійність (збіжність), правильність $\left(\Delta_{z}=0.79 \leq \max \Delta_{z}=5.0, \delta=0.21 \leq \max \delta=0.26, a=0.48, r=0.99997>0.9976\right.$ гіпоксантину та $\Delta_{z}=0.83 \leq \max \Delta_{z}=5.0, \delta=0.17 \leq \max \delta=0.28, a=0.21, r=0.99997>0.9976$ гуанозину) та діапазон застосування запропонованої методики.

РАЗРАБОТКА И ВАЛИДАЦИЯ МЕТОДИКИ ОПРЕДЕЛЕНИЯ СОПУТСТВУЮЩИХ ПРИМЕСЕЙ В ТАБЛЕТКАХ РИБОКСИН

Н.В.Росада, Н.Ю.Бевз, В.А.Георгияни

Ключевые слова: стандартизация; рибоксин; таблетки; сопутствующие примеси; метод ВЭЖХ Рибоксин (инозин) применяют в медицинской практике для лечения сердечно-сосудистых заболеваний, поэтому количество готовых лекарственных форм, содержащих в качестве активного фрармацевтического ингредиента именно это вещество, на фрармацевтическом рынке Украины постоянно растет. При разработке методик контроля качества на готовую лекарственную форму, содержащую одно действующее вещество, целесообразно кроме испытаний на идентификацию и количественное определение также проводить испытания на содержание сопутствующих примесей. В предлагаемой работе приводятся данные по разработке методики определения сопутствующих примесей (гипоксантин, гуанозин) рибоксина в таблетках с использованием метода высокоэфффективной жидкостной хроматографии. Определение проводили на колонке размером 125×4 мм, заполненной сорбентом "Lichrospher 60 RP select B» с размером частиц 5 мкм, использовали подвижную фазу на основе фоссратного буферного раствора с рН 3,5 и УФ-детектирование при длине волны 250 нм. Изученные валидационные характеристики с использованием критериев приемлемости для допусков содержания не более 0,5\% для каждой из примесей подтверждают специфичность (отсутствие влияния вспомогательных веществ), линейность, прецизионность (сходимость), правильность $\left(\Delta_{z}=0.79 \leq \max \Delta_{z}=5.0\right.$, $\delta=0.21 \leq \max \delta=0.26, a=0.48, r=0.99997$ гипоксантина $u \Delta_{z}=0.83 \leq \max \Delta_{z}=5.0, \delta=0.17 \leq \max \delta=0.28, a=0.21$, $r=0.99997$ гуанозина) и диапазон применения предлагаемой методики. 
Riboxin is used for improvement of the functional recovery after craniocerebral traumas; it affects restoration of the level of the associated protein GAP-43 growth in the hippocampus [1], and has good indications for treating patients suffered a stroke [2]. Recently, a lot of dosage forms containing riboxin appear at the domestic pharmaceutical market. The State Pharmacopoeia of Ukraine (SPhU) recommends to determine related impurities both in dosage forms and in substances.

The inosine substance is obtained by microbiological synthesis, and hypoxanthine and guanosine can be by-products of this synthesis [3]. Their certain amount (not more than $0.5 \%$ ) is regulated in the substance $[4,5,6]$. For the further substantiation for either inclusion or exclusion of impurities in the specification it is advisable to determine these related impurities in the finished dosage form.

Nowadays, there are three requirements for drug substances and medicines: efficacy, safety, and quality. Recently, in drug quality control the attention is paid to determination of related impurities [7, 8, 9], which may have a significant impact on the human health due to potential teratogenic, mutagenic or carcinogenic effects. Therefore, control and monitoring of impurities is a pressing question when developing and producing drugs. In accordance with the Pharmacopoeia of the People's Republic of China [5], the manufacturer [4] and the State Pharmacopoeia of the Russian Federation [6] the HPLC method is used for the assay of riboxin and determination of related impurities. The equipment change and technological peculiarities of tablet production need improvement of the existing method or development of the new one.

The aim of our research was to develop the method for determination of related impurities in riboxin tablets by HPLC, and validate it in accordance with the SPhU requirements to drugs in the form of tablets $[10,11,12]$.

The study object was "Riboxin" tablets with the content of $200 \mathrm{mg}$ of the active substance (excipients potato starch, sugar, hypromellose, sodium croscarmellose, povidone K25 and magnesium stearate). The

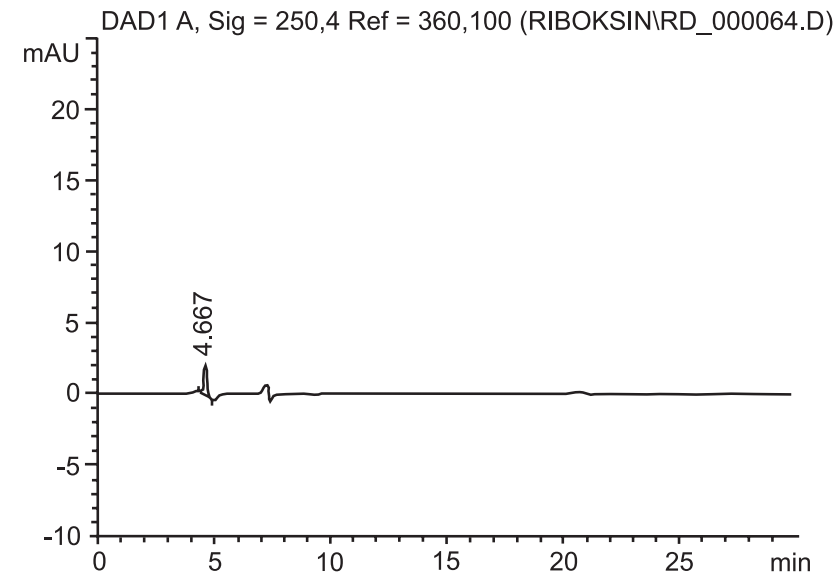

Fig. 1. The chromatogram of the placebo solution. reference samples of 9- $\beta$-D-ribofuranosyl hypoxanthine (riboxin (inosine), batch 1 from 20.04.2012 (RS, $\mathrm{SPhU}$ ); guanine-9- $\beta$-hypoxanthine (guanosine), batch 0B006736 from 09.08.2010; 6-hydroxypurine (hypoxanthine), batch 0L006460 from 09.07.2010 were used. Analytical studies were performed by the HPLC method on an Agilent 1200 chromatograph ("Agilent Technologies", Germany) using OHAUS AP 250D laboratory balances ("Ohaus Corporation", USA), and the measuring glassware of class A.

Determination of related impurities of riboxin in tablets was carried out by the HPLC method. To determine related impurities in the test solution the diluted solution of riboxin impurities was used as the reference solution. Since the method for determination of related impurities must be validated according to the $\mathrm{SPhU}$ requirements, the main validation characteristics were studied: specificity, linearity, precision (convergence), accuracy, and the application range.

The tolerances of the content of related impurities of riboxin in the finished dosage form is not more than $0.5 \%$. Therefore, during validation the parameters for $\mathrm{B}=0.5 \%$, i.e. the maximum uncertainty of the analysis $\left(\Delta_{\mathrm{As}}\right)$ must be not more than $5.0 \%$, were the evaluation criteria of this method $[8,13,14,15]$.

The specificity of the method is confirmed by the absence of the effect of excipients. The chromatogram of the placebo solution shows it (Fig. 1).

The suitability of the chromatographic system is performed since the peaks of related substances (hypoxanthine and guanosine) and the peak of the basic substance (riboxin) are completely separated (Fig. 2).

The linearity, precision, accuracy, and the application range of the given method were determined on the model mixtures with the known content of related impurities in the range from $25 \%$ to $125 \%$ relative to the maximum permissible value. Both the reference solution and model solutions were prepared according to the same method; the actual values $\mathrm{X}_{\mathrm{i}}$ from the ratio of $X=S_{i} / S_{\text {st }} \cdot 100 \%$ were equal in relation to the actual weights of the riboxin substance taken for preparation of the model solution and the

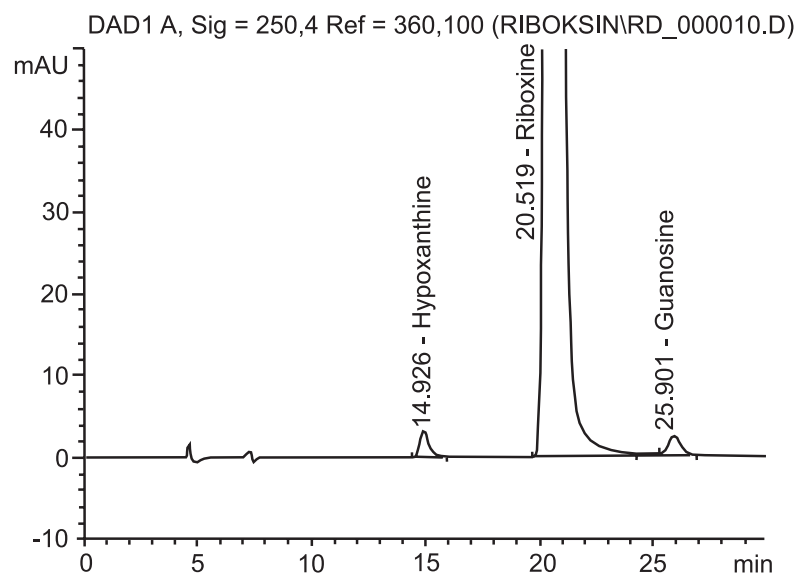

Fig. 2. The chromatogram of the chromatographic system suitability. 


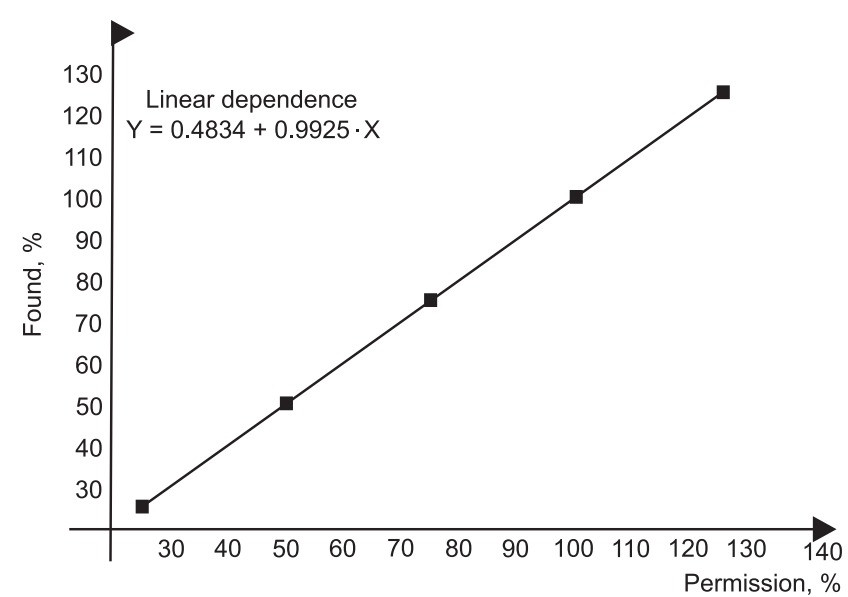

Fig. 3. The linear dependence of the peak area on the hypoxanthine concentration.

reference solution. The working concentration of the test solution and the reference solution was approximately $10 \mu \mathrm{g} / \mathrm{ml}$. The linearity of dependence of the peak areas of hypoxanthine and guanosine solutions on the concentration in the range of approximately $2.5 \mu \mathrm{g} / \mathrm{ml}$ to $12.5 \mu \mathrm{g} / \mathrm{ml}$ was determined. The linear dependence of the peak area on the concentration of related impurities of hypoxanthine and guanosine in the normalized coordinates is presented in Fig. 3 and Fig. 4, respectively.

Calculation of parameters of the linear dependence $Y_{i}=b \times X_{i}+a$ for related impurities of riboxin (hypo-xanthine and guanosine) was performed by the least squares method (Tab. 1).

As can be seen from Table 1, all requirements for the linear dependence parameters are met, i.e. the linearity of the method for determination of related impurities is confirmed within the whole range of concentrations (25-125\%). The high value of the correlation coefficient also meets the requirements of the acceptance criteria $(r=0.9976)$ and confirms the linearity of dependence between the "introduced" and "found" amount of the substance.

The data of Tab. 2 and 3 show that for both hypoxanthine and guanosine the method of analysis is characterized by sufficient precision (convergence). The value of

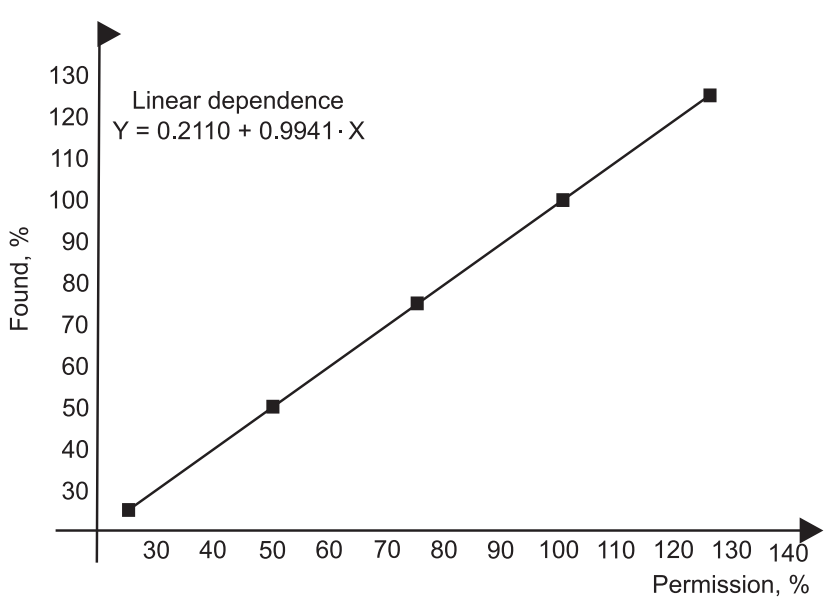

Fig. 4. The linear dependence of the peak area on the guanosine concentration.

the relative confidence interval of value $\mathrm{Z}$ found is less than the critical value for convergence of results (5.00\%).

The tests for the tablets studied showed that in the chromatograms of the test solution for "Riboxin" drug only one impurity (guanosine) in the amount of approximately $0.12 \%$ was determined (Fig. 5).

Therefore, it has been found that the amount of related impurities in "Riboxin" tablets does not increase compared to the riboxin substance, i.e. the impurity identified is the technological impurity of the sub-

DAD1 A, Sig $=250,4$ Ref $=360,100($ RIBOKSINIRD_000008.D)

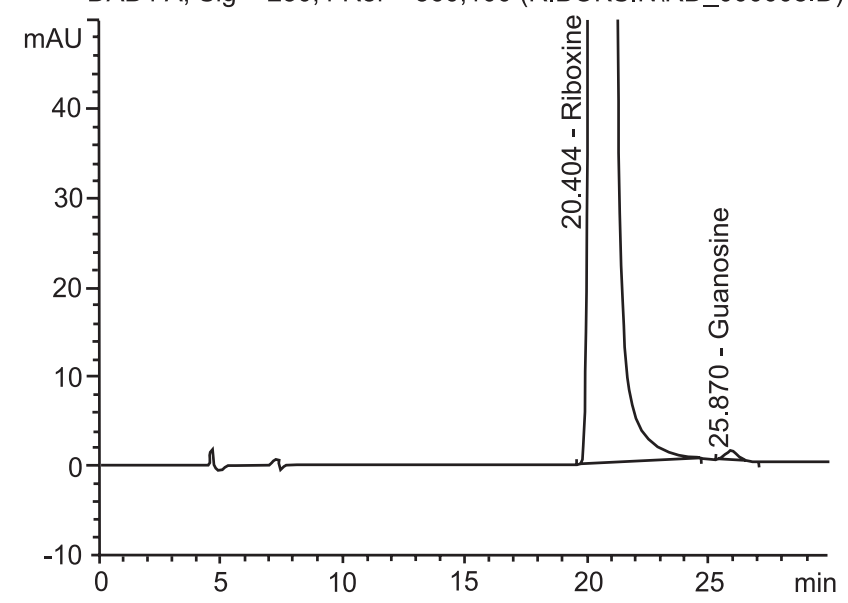

Fig. 5. The chromatogram of the test solution.

Table 1

Metrological characteristics of the linear dependence for riboxin

\begin{tabular}{|c|c|c|c|c|c|c|}
\hline & $b$ & $\mathrm{~S}_{\mathrm{b}}$ & $a$ & $\mathrm{~S}_{\mathrm{a}}$ & $\mathrm{S}_{\mathrm{r}}$ & $r$ \\
\hline Hypoxanthine & 0.9925 & 0.0028 & 0.4834 & 0.2252 & 0.3028 & 0.99997 \\
\hline \multirow[t]{2}{*}{ Criteria } & & & $\begin{array}{c}<1.8946^{*} \\
0.2252=0.43\end{array}$ & & & \multirow[t]{2}{*}{$>0.9976$} \\
\hline & & & $<2.1$ & & & \\
\hline Guanosine & 0.9941 & 0.0027 & 0.2110 & 0.2191 & 0.2946 & 0.99997 \\
\hline \multirow[t]{2}{*}{ Criteria } & & & $\begin{array}{c}<1.8946^{*} \\
0.2191=0.42\end{array}$ & & & \multirow[t]{2}{*}{$>0.9976$} \\
\hline & & & $<2.1$ & & & \\
\hline
\end{tabular}


Table 2

The results of analysis of the model mixtures and their statistical processing for hypoxanthine determination

\begin{tabular}{|c|c|c|c|c|c|}
\hline $\begin{array}{l}\text { No. of the } \\
\text { model } \\
\text { solution }\end{array}$ & $\begin{array}{c}\begin{array}{c}\text { The sample weight } \\
\text { of hypoxanthine RS, } \\
\mathrm{mg} \\
\mathrm{m}_{\mathrm{st}}=9.9 \mathrm{mg}\end{array}\end{array}$ & $\begin{array}{l}\text { Found in } \% \text { to the } \\
\text { introduced } \\
\left(\mathrm{X}_{\mathrm{i}}=\mathrm{C}_{\mathrm{i}} / \mathrm{C}_{\mathrm{st}} \%\right)\end{array}$ & $\begin{array}{l}\text { The area mean } \\
\text { values }\left(\mathrm{S}_{\mathrm{i}}\right) \\
\left(\mathrm{S}_{\mathrm{st}}=259.80\right)\end{array}$ & \begin{tabular}{|c|} 
Found in $\%$ to the \\
concentration of the \\
reference solution \\
$\left(\mathrm{Y}_{\mathrm{i}}=\mathrm{S}_{\mathrm{i}} / \mathrm{S}_{\mathrm{st}} \%\right)$
\end{tabular} & $\begin{array}{l}\text { Found in } \% \text { to the } \\
\text { introduced } \\
Z_{i}=100 \cdot\left(Y_{i} / X_{i}\right) \%\end{array}$ \\
\hline 1 & 2.5 & 25.25 & 66.50 & 25.60 & 101.39 \\
\hline 2 & 2.5 & 25.25 & 66.50 & 25.60 & 101.39 \\
\hline 3 & 5.0 & 50.51 & 131.50 & 50.62 & 100.22 \\
\hline 4 & 5.0 & 50.51 & 132.10 & 50.85 & 100.67 \\
\hline 5 & 7.5 & 75.76 & 195.90 & 75.40 & 99.52 \\
\hline 6 & 7.5 & 75.76 & 196.50 & 75.64 & 99.84 \\
\hline 7 & 10.0 & 101.01 & 260.20 & 100.15 & 99.15 \\
\hline 8 & 12.5 & 126.26 & 327.80 & 126.17 & 99.93 \\
\hline 9 & 12.5 & 126.26 & 327.20 & 125.94 & 99.75 \\
\hline & & & & Mean, \% & 99.59 \\
\hline \multicolumn{5}{|c|}{ Relative standard deviation, RSDz, $\%$} & \multirow[b]{2}{*}{0.34} \\
\hline & & & \multicolumn{2}{|c|}{$R S D_{Z}(\%)=\sqrt{\frac{\sum_{i}\left(Z_{i}-\bar{Z}\right)^{2}}{n-1} \cdot \frac{100}{\bar{Z}}}$} & \\
\hline & & & \multicolumn{2}{|c|}{$\begin{array}{r}\text { Relative confidence interval, } \\
\Delta_{z}(\%)=t(95, \mathrm{n}-1) \times R S D_{z}=1,860 \times R S D_{z^{\prime}} \%\end{array}$} & 0.79 \\
\hline \multicolumn{5}{|c|}{$\begin{array}{r}\text { Critical value for convergence of results } \Delta_{\text {Ass }} \% \\
\text { (limit uncertainty) } 5.0\end{array}$} & 5.0 \\
\hline \multicolumn{5}{|c|}{ Systematic error $\delta=|\bar{Z}-100|$} & 0.21 \\
\hline \multicolumn{5}{|c|}{$\begin{array}{r}\left.\delta \%=\frac{\Delta_{z}}{\sqrt{n}}=\frac{\Delta_{z}}{3}=\frac{0.7924}{3}=0.26(0.21 \leq 0.26) \text { if not satisfied } 1\right), \\
\text { then } \delta \leq 0.32 \times 5.0=1.6 \%(0.26 \leq 1.6)\end{array}$} & $\begin{array}{l}\text { Is not satisfied } \\
\text { Satisfied }\end{array}$ \\
\hline \multicolumn{5}{|c|}{ The overall conclusion of the method } & Correct \\
\hline
\end{tabular}

stance. Due to this fact we consider it is possible to include the limitation for impurities in the specifications for tablets, which is similar to the manufacturer's Analytical Normative Documents for the substance: not more than $0.5 \%$ of guanosine and not more than $0.5 \%$ of hypoxanthine.

\section{Experimental Part}

The method for determination of related impurities:

Test solution. Place approximately $68.7 \mathrm{mg}$ (accurate weight) of the powdered tablets into a $250 \mathrm{ml}$ flask, add $150 \mathrm{ml}$ of water, stir the solution obtained for 10-15 min, or place in an ultrasonic bath for $10 \mathrm{~min}$, and cool. Then dilute the solution to the volume with the same solvent, mix, and filter through a $0.45 \mathrm{mi}-$ crons membrane filter rejecting the first $5 \mathrm{ml}$ of the filtrate.

Reference solution (a). Place $10.0 \mathrm{mg}$ of guanosine into a $100 \mathrm{ml}$ flask, dissolve in warm water, cool, dilute the solution obtained to the volume with the same solvent, and mix.

Reference solution (b). Place $10.0 \mathrm{mg}$ of hypoxanthine into a $100 \mathrm{ml}$ flask, dissolve in warm water, cool, dilute the solution obtained to the volume with the same solvent, and mix.

Reference solution (c). Place $1.0 \mathrm{ml}$ of the Reference solution (a) and $1.0 \mathrm{ml}$ of the Reference solution (b) into a $100 \mathrm{ml}$ flask, dilute the solution obtained to the volume with water, and mix.

Reference solution (d). Place $20.0 \mathrm{mg}$ of riboxin into a $100 \mathrm{ml}$ flask, dissolve in water, dilute the solution obtained to the volume with the same solvent, and mix.

Reference solution (e). Mix the Reference solution

(c) with the Reference solution (d).

Chromatography is carried out in the conditions described below:

- Column $-125 \times 4 \mathrm{~mm}$ i.d., filled with "Lichrospher 60 RP select B" sorbent (5 $\mu$ m particles) or similar, for which the requirements of the "Chromatographic system suitability" test are met;

- The flow rate of the mobile phase $-0.2 \mathrm{ml} / \mathrm{min}$;

- Detection - at the wavelength of $250 \mathrm{~nm}$;

- Column temperature $-35^{\circ} \mathrm{C}$.

For chromatography $20 \mu$ of the Test solution, the Reference solution (c) and the Reference solution (e) were used, at least 3 chromatograms should be obtained. 
Table 3

The results of analysis of the model mixtures and their statistical processing for guanosine determination

\begin{tabular}{|c|c|c|c|c|c|}
\hline $\begin{array}{l}\text { No. of the } \\
\text { model } \\
\text { solution }\end{array}$ & $\begin{array}{c}\text { The sample weight } \\
\text { of guanosine } \mathrm{RS}, \mathrm{mg} \\
\mathrm{m}_{\mathrm{st}}=9.9 \mathrm{mg}\end{array}$ & $\begin{array}{l}\text { Found in } \% \text { to the } \\
\text { introduced } \\
\left(X_{i}=C_{i} / C_{s t} \%\right)\end{array}$ & $\begin{array}{l}\text { The area mean } \\
\quad \text { values }\left(\mathrm{S}_{\mathrm{i}}\right) \\
\left(\mathrm{S}_{\mathrm{st}}=147.70\right)\end{array}$ & $\begin{array}{l}\text { Found in } \% \text { to the } \\
\text { concentration of the } \\
\text { reference solution } \\
\left(Y_{i}=S_{i} / S_{s t} \%\right)\end{array}$ & $\begin{array}{l}\text { Found in } \% \text { to the } \\
\text { introduced } \\
Z_{i}=100 \cdot\left(Y_{i} / X_{i}\right) \%\end{array}$ \\
\hline 1 & 2.5 & 25.25 & 37.30 & 25.25 & 100.00 \\
\hline 2 & 2.5 & 25.25 & 37.50 & 25.39 & 100.55 \\
\hline 3 & 5.0 & 50.51 & 74.70 & 50.58 & 100.14 \\
\hline 4 & 5.0 & 50.51 & 74.70 & 50.58 & 100.14 \\
\hline 5 & 7.5 & 75.76 & 111.40 & 75.42 & 99.55 \\
\hline 6 & 7.5 & 75.76 & 111.40 & 75.42 & 99.55 \\
\hline 7 & 10.0 & 101.01 & 147.70 & 100.00 & 99.00 \\
\hline 8 & 12.5 & 126.26 & 185.90 & 125.86 & 99.68 \\
\hline 9 & 12.5 & 126.26 & 186.20 & 126.07 & 99.85 \\
\hline \multirow{2}{*}{\multicolumn{5}{|c|}{ Relative standard deviation, $\mathrm{RSDz}, \%$}} & 99.83 \\
\hline & & & & & \multirow[b]{2}{*}{0.45} \\
\hline \multicolumn{5}{|c|}{$R S D_{z}(\%)=\sqrt{\frac{\sum_{i}\left(Z_{i}-\bar{Z}\right)^{2}}{n-1}} \cdot \frac{100}{\bar{Z}}$} & \\
\hline \multicolumn{5}{|c|}{$\begin{array}{r}\text { Relative confidence interval, } \\
\Delta_{z}(\%)=t(95, \mathrm{n}-1) \times R S D_{z}=1.860 \times R S D_{z^{\prime}} \%\end{array}$} & 0.83 \\
\hline \multicolumn{5}{|c|}{$\begin{array}{r}\text { Critical value for convergence of results } \Delta_{\text {As }^{\prime}} \% \\
\text { (limit uncertainty) } 5.0\end{array}$} & 5.0 \\
\hline \multicolumn{5}{|c|}{ Systematic error $\delta=|\bar{Z}-100|$} & 0.17 \\
\hline \multicolumn{5}{|c|}{$\begin{array}{r}\left.\delta \%=\frac{\Delta_{Z}}{\sqrt{n}}=\frac{\Delta_{Z}}{3}=\frac{0.8337}{3}=0.28(0.17 \leq 0.28) \text { if not satisfied } 1\right) \\
\text { then } \delta \leq 0.32 \times 5.0=1.6 \%(0.28 \leq 1.6)\end{array}$} & $\begin{array}{l}\text { Is not satisfied } \\
\text { Satisfied }\end{array}$ \\
\hline \multicolumn{5}{|c|}{ The overall conclusion of the method } & Correct \\
\hline
\end{tabular}

The system suitability test: The chromatography system is considered to be suitable if the following conditions are performed:

- resolution of hypoxanthine and riboxin should be at least 4.0;

- resolution of guanosine and riboxin should be at least 2.0.

Preparation of the mobile phase:

Place $4.80 \mathrm{~g}$ of potassium dihydrogen phosphate, $0.24 \mathrm{~g}$ of sodium heptanesulfonate into a $1000 \mathrm{ml}$ flask, dissolve in $700 \mathrm{ml}$ of water, add $0.20 \mathrm{~g}$ of triethylamine and $20 \mathrm{ml}$ of methanol, and mix the solution obtained.
Then, adjust $\mathrm{pH}$ to 3.5 with the concentrated phosphoric acid by potentiometry. Dilute the solution obtained to the volume of $1000 \mathrm{ml}$ with water and mix.

\section{Conclusions}

1. The method for determination of related impurities has been developed; its suitability has been proven by the HPLC method.

2. The validation study for the "Related impurities" test performed confirms the compliance of such characteristics as specificity, linearity, precision (convergence), accuracy, and the application range with the acceptance criteria.

\section{References}

1. Shlomit Dachir, Dalia Shabashov, Victoria Trembovler, Alexander G. Alexandrovich, Larry I. Benowitz, Esther Shohami. Inosine improves functional recovery after experimental traumatic brain injury. Brain Research, 2014, No.1555, pp.78-88.

2. Laila Zai, Christina Ferrari, Carlie Dice, Sathish Subbaiah, Leif A. Havton, Giovanni Coppola, Daniel Geschwind, Nina Irwin, Eric Huebner, Stephen M. Strittmatter, Larry I. Benowitz. Inosine Augments the Effects of a Nogo Receptor Blocker and of Environmental Enrichment to Restore Skilled Forelimb Use after Stroke. Journal of Neuroscience, 2011, No.31, pp.5977-5988.

3. Пат. РФ 1755583 (1994). Заявл.: 31.10.1990. Опубл. 30.08.1994 [Электронный ресурс] Режим доступа http://patents.su/0-1755583-sposobpolucheniya-inozina.html.

4. Drug master file (for Inosine). "Starlake Bioscieence Co.", China, 2007, p.68.

5. Китайська фармакопея. T. 2. People's Medical Publishing House, 2005, pp.438-440.

6. Государственная фармакопея Российской Федерации Ч. 1. Научный центр экспертизы средств медицинского применения. РИБОКСИН (ФС 42-0275-07), 2007, c.624-627. 
7. Александров А. В. Вызовы и возможности документа ICH Q10 «Фармацевтическая система качества». Промышленное обозрение, 2008, №4(9), c.19-21.

8. FDA / Guidance for Industry-ANDAs: Impurities in Drug Products. Rockville, MD, 2010, p.7.

9. Jiben Roy. Pharmaceutical Impurities - A Mini-Review. AAPS Pharm. Sci. Tech., 2002, Vol. 3(2), p.7.

10. Гризодуб А. И. Стандартные процедуры валидации методик контроля качества лекарственных средств. Фармаком, 2006, №1/2, с.3-44.

11. Державна фармакопея Украӥни / Державне підприємство «Науково-експертний фармакопейний центр». 1-е вид. Х.: РІРЕГ, 2001,556 c.

12. Настанова «Лікарські засоби. Фармацевтична розробка» (Настанова 42-3.1:2004). К.: МОРИОН, 2004, 15 c.

13. Державна фармакопея України / Державне підприємство «Науково-експертний фармакопейний центр». 1-е вид. Доп. 1. Х.: РІРЕГ, 2004, $494 \mathrm{c.}$

14. Державна фармакопея України / Державне підприємство «Науково-експертний фармакопейний центр». 1-е вид. Доп. 2. Х.: РІРЕГ, 2008, $617 c$.

15. Стандартизованная процедура валидации методик контроля содержания примесей в готовых лекарственных средствах методом жидкостной хроматографии / А. И. Гризодуб, Д. А. Леонтьев, Т. Н. Доценко, В. А. Загорий. Фармаком, 2005, №2-3, с.78-94.

Надійшла до редакції 12.10 .2015 p. 